\title{
Study on the Reformation and Development of Rural Mass Sport in Our Country
}

\author{
Deng Minwei ${ }^{1}$, QiaoYaJun ${ }^{2}$ \\ 1.Department of P.E. in Jinan University Guangzhou 510632 \\ 2. Zhengzhou shengda college of economic and trade Zhengzhou 451191
}

Keywords: Chances, rural areas, three transforming, mass sport

\begin{abstract}
The speed up of industrialization, urbanization and marketization in rural economy changes the production method, life style, communication pattern, and mental attitude in rural areas. This kind of changing influences the rural mass sport development deeply. When we speed up the urbanization process, we change the agricultural production method. More and more machines and chemical products are applied in the agricultural production. This new production method reduces the population working on planting and the peasants' physical consuming, which make sport annecessary part of life. The enthusiasm and demands of mass sport consuming is increasing, and the high-speed developed economy lays a solid foundation for people to purchase sport goods. The marketized reformation turns the planned economy to market economy. Also, the publicity of mass sport facilities is sure to force the government to increase supply. The profit-oriented market economy and budget limitation make these facilities open to the mass non-freely. The correct guidance to the rural mass sport will strengthen the peasants' body constitutions. It will help to speed up the construction of new countryside.
\end{abstract}

\section{Introduction}

It is certain that the Interactive development of urbanization and mass sport would lead a deep influence to the new countryside construction. The government functions are transforming from the management function which arranges the whole social production and distribution to the service function which provides public goods and services to make up for the marketing fail. It will push the government to provide more public sport facilities and improve the utilization rate of them in order to meet the requirements of rural areas.

\section{The understanding of related concept}

The understanding of rural areas in the new epoch

From the traditional definition, rural areas mean the peasants' living areas. People there use the traditional production method and acquire living material from the land. So the rural areas we discuss here are mainly considered from the production method and the population gathering level.

However, an inevitable change comes out. As the development of modern economy and technology, the line between urban and rural areas becomes vague. This kind of vagueness not only shows in the regional overlap but also in the inter-affection between the production methods. Besides, with the migration of labor force, China emerges a special kind of labor group--rural workers. They don't have city registration, but they live in the city for a long period and work on other industries other than planting. It's controversial to say whether they belong to the country group. However, according to the Marxist sociological thoughts, to classify from production method is more reasonable. Although rural workers suffer from the unbearable treatment and high strengthen work, once the life style stables, they become the special group of the urban mass sport. The embedding of the region and spirit which brought by this production method are transforming these farmers into the modern industrial workers with high discipline, and lighten the ties that enforce to them by the region, blood, and production method. This transforming of character bring the country income, along with the new living method and living idea, which do good to the spread of healthy consuming ideas. 
The meaning of rural areas and mass sport

According to the textbook, mass sport means the social cultural practice which mass social members do in their spare time, taking physical practice as main tool, to improve the whole health level. Under this basis, people exceed themselves unceasingly and promote the social material and spiritual civilization. As for our country, in order to understand the rural mass sport, we should consider from the following aspects:

(1)T o understand from the opposite side. A s w e all know, the opposite of $\mathrm{m}$ ass sport is talent sport, or those talents who have high sport quality and work on the high level sport competitions. By contrast, the purpose of the masses taking physical activities is mainly for improving the health level and for fun.

(2)The other opposite m eaning of $m$ ass sport is professional sport. Professional sport is to take sport as a profession. They get paid from the sport competitions. The purpose is not just for health any more.

\section{The function and current situation of rural mass sport}

Strengthen the peasants' health, and improve the peasants' quality comprehensively

Strengthen the peasants' health can improve their health level and reduce their medical expenses which relatively increases their income. Sports can strengthen people's body health, but it differs from the manual labour. Recently, because of the appliance of technical tools, the manual labour of peasants has obviously reduced. In addition, they don't take any exercises, as a result, the physical condition declines. The statistics of Ministry of Health shows that the incidence rate of tuberculosis and cancer in country increases year by year, while the medical expenses are remaining high. Peasants have difficulties in medical care, and the sickness leads them to poverty. So, develop sports is the main way to reduce the peasants' medical expenses and increase their income.

Maintain the country's security, and raise the production efficiency

From one hand, the development of rural mass sport provides the farming qualified labour force, from the other hand; it promotes mutual understandings of individuals, and builds a good environment for the social peace. Through exercises--an active and healthy life style, peasants can lead their families and individuals to a harmony development, and speed up the construction of rural spiritual civilization. Finally, they help to build a good social security environment. Good social environment and healthy bodies provide guarantees for agricultural production, and raise the production efficiency.

Flourish rural culture, and speed up the construction of rural spiritual civilization

With the revolution of production method, peasants' life style changes. As the massive use of machines, chemical fertilizers and pesticides, the peasants' working time and strength reduce. Relatively, they have more spare time. This situation is much easier for them to pick up unhealthy living habits such like gambling, superstition and so on. Shown from the investigation of Henan Publicity Department, peasants in Henan take watching TV as the main entertainment, playing mah-jong and poker cards the second. The same situation happens in Chongqing. Playing mah-jong ranking NO.1, with the rate of $49.8 \%$, watching TV takes the second, with the rate of $43.2 \%$, and $8.1 \%$ of them would like to educate children in their spare time. However, this unscientific consuming idea and the bad relationship issues from gambling are sure to affect the social harmony in rural areas. Developing rural mass sport would bring peasants healthy life style, flourish rural culture, and speed up the construction of rural spiritual civilization.

\section{Industrialization, urbanization and marketization bring rural mass sport development opportunities}

The sharp increase of rural productivity raises peasants' income and reduces the manual labor

Although in the entire economic structure, the proportion of rural economy is dropping constantly, judging from the recent decades, it keeps growing in a high speed. The amount of people working on agriculture is reducing, while the peasants' income is increasing, which makes the Engel's coefficient keeps dropping.

The changing of rural production method increases the demands of sport consumptions. First of all, the machines and modern technology save the labor force, and increase the peasants' spare time. Secondly, the raising of income in rural families promotes the consuming ability. Peasants have more money so that they 
can spend more in sport goods and services. Thirdly, the flourishing of economy promotes the peasants' thoughts. The attention they pay to sport consumption varies directly with the economic development. As a whole, the changing of rural production method increases the demands of sport consumptions. As the flourishing of rural economy and the changing of peasants' life style and thoughts, the demands of rural mass to exercises increase deeply. They have stronger will to participate in the sport activities.

The marketization of sport industry make the supply of sport goods various and multi-tired, meets the needs of different levels of consumers

The industrialization of sport develops greatly abroad, and it becomes a new essential industry in some countries. With the highly development of modern intermediary, the degree of sport' industrialization, marketization and globalization grow deeper, and it leads a redistribution and a combination of the current market. The development of this industrialization makes the entire rural sport consumption an inevitable component. Looking for new profit and open the rural sport market become an important task in many sport facility factories. It will increase the supply of the adequate sport facilities, which balances the supply and demand in rural areas.

The series of supports from the government rises up the peasants' activities for sport consumption

Mass sport brings the people healthy bodies, which is bound to increase the total social output, reduce the medical expenses, raise the national cohesion, and decrease the social conflict and so on. As a result, any government will carry out some measures in developing mass sport. In our country, the government focuses on the development of mass sport in rural areas where takes the majority population by carrying out some actual measures to increase the rural sport facilities.

\section{The urbanization and marketization of rural economy}

The industrialization, urbanization and marketization of rural economy are pushed in a passive way. It comes out under the huge change of coastal regions in these three aspects, but not the result of self evolution of the economy and society.

\section{The speed of urbanization in rural economy}

To achieve the transformation of labour force to urban area is not only a common tendency of social structure change, but also an objective need of increasing peasants' income. Obviously, it's one of the essential factors of pushing the rural mass sport movement. After the long-time efforts the government makes, the policy is more reasonable, and it encourages the development of non-agricultural industry. Besides, the government takes education and training as tools to promote the labour qualities and skills, so that they can adapt to the objective requirements of the industrial development, and provide human capital for the high-level urbanization. Also, the government is improving the system for labour transforming, such like household registration system, education problems of rural workers' children. All of these measures speed up the urbanization in our country greatly.

The speed of marketization in rural economy

After we enter into the WTO, the agreements we make with other countries become the first chain to lock the marketing revolution in orientations. As an honest socialized country that has a long culture tradition, firstly we won't tear up any agreements. Secondly, the living of many companies and individuals in our country is closely related to the global market. These export-oriented companies rely on the global market, and they became the second chain to lock the marketing revolution. Thirdly, the boom of export trade relieves the employment pressure. The increase of government receipts provide capital supports in defusing various conflicts brought by the revolution. The protection of market economy becomes the forth chain. As a result, the marketing revolution has been improving step by step since the new century comes, and our status has been approved by majority countries in the world.

\section{Changing in supply and consuming of sport goods brought by urbanization and marketization}

Uurbanization and marketization change the rural life style, and influence the management of mass sport under planned economy deeply. They also change the supply and consuming of sport goods. 
More resources are used in production under planned economy, and the sport is ignored. The limit sport resources are often distributed to the talent sport. The athletes who are hopeful to win in the high-profile international sporting events can get lots of capital supports from the country, while the mass sport is ignored. The goal of planned-economic countries in national sport is to get more medals than the western countries. It can be showed as the success and superiority of political systems.

\section{The motivation of people taking part in sport, and the change of supply brought by the marketing system}

\section{The attraction of sport facilities}

Good sport facilities and convenient consuming condition are likely to attract more rural mass to take part in sport activities. For example, before the East-European countries reformed, mass sport developed sharply in the 1960s 1980s. During this period, the government built many sport fields, swimming pools, and playgrounds with manual lawn. The sport facilities attracted more and more people to join the sport activities. Mass sport development among this period is called the attraction of sport facilities.

\section{The guidance of policy}

The development of rural mass sport can't do without the government's guidance. There are both economic and political factors. The socialization of human being highlights the importance of mass sport organization. Without the government's active organization and guidance, the rich peasants are not likely to develop good sport habits. According to Confucius, people should be cultivated after rich. If the country only makes people rich, but not cultivates them, the peasants would misuse the wealth, and produce bad social influences. The spread of gamble and waste on the weddings and funerals show that if the government doesn't provide correct guidance, the peasants would misuse the wealth, which is not conform to the social development. So, government plays an important role in the rural mass sport development.

\section{The acquiring and lasting of good habits}

Habit is formed in long life time, and it is not easy to change. To define from the separate characters, one is to pick up, the other is to last. So, the pick up of good living and sport habits should be continuing. The investigation shows that students will keep on doing exercises in quite a long time after they leave school if they pick up good sport habit in school. The popularization of compulsory education will make more peasants to do exercises after they leave school.

\section{The requirement of living}

The appliance of industry in agriculture reduces the physical output of peasants, and increases their spare time. In this way, peasants may and should do some necessary exercises to keep healthy. After the industrialization and urbanization, the labour strength increases, and people should do some exercises to recover physical power.

\section{The strategy of booming rural mass sport in our country}

Transform the agricultural production method further, promote the modernization and marketization of agriculture, and increase peasants' income and spare time

The modernization and marketization of agriculture in our country is still not high. To increase peasants' income and spare time is still the most important task. Use urbanization, industrialization and marketization as tools, to achieve the goal of increasing peasants' income and developing rural economy.

Strengthen the guiding role of grass-roots Party organizations, and encourage the acquiring of good living habits

To speak from the reality, lacking of organizing and guiding becomes the main block of sport consuming in backward areas. Strengthen the sport habits in compulsory education period and provide guidance after graduation will lead people into a healthier life style.

Improve the rural sport facilities, and promote the publicity of these facilities

Lacking of sport fields and facilities is the main difficulty in promoting the rural mass sport. So we must raise funds from all respects to purchase sport facilities, and enlarge the publicity of these facilities. First, we should take advantage of financial transforming, and arrange the special fund for purchasing rural sport 
facilities. Second, we can launch the social donation. Third, we can attract investment for building rural sport facilities through deduction of tax and other preferential policies.

Strengthen the propaganda, propose healthy consuming, and carry forward sport culture

It has been testified that the consuming ideas of peasants are more short dated. As the wealthy of rural areas, the expenses for enlarging production capacity and education are not growing relatively. Peasants spend more on the house building, weddings and funerals, and gambling.

As described previously, the human action, which the institutional economics exposes is more likely to be influenced by constitutions and culture. These potential cultural genes determine whether people would choose a healthy life style and join the sport activities. As a result, we should propagate advanced culture, leading peasants to become the rich, cultivated and healthy new peasants.

\section{References}

[1] The research group of the investigation and study on the current situation of Chinese mass sport, The Investigation and Study on the Current Situation of Chinese Mass Sport[M],Beijing, Beijing sport university press.1998(3)

[2] Marshall McLuhan, Understanding Media : The Extensions of Man[M], Beijing, The Commercial Press.2000

[3] Li Ying, The Analyze and Research on the Current Situation of Migrants' Consumption on Sport in Chongqing Province, sport science.2004-4:21-23 